JURNAL NOMINAL / VOLUME VI NOMOR 2 / TAHUN 2017

\title{
PENGARUH EARNING PER SHARE, ARUS KAS KEGIATAN OPERASI, LIKUIDITAS DAN STRUKTUR MODAL TERHADAP KEBIJAKAN DIVIDEN TUNAI PADA PERUSAHAAN GO PUBLIC YANG TERDAFTAR PADA INDEKS KOMPAS 100 PERIODE 2011 - 2015
}

\author{
Sari Kurniawati \\ Akuntansi Universitas Negeri Yogyakarta \\ sarikurniawati71@gmail.com
}

\author{
Isroah \\ Staf Pengajar Jurusan Pendidikan Akuntansi Universitas Negeri Yogyakarta
}

\begin{abstract}
Abstrak: Pengaruh Earning Per Share, Arus Kas Kegiatan Operasi, Likuiditas dan Struktur Modal terhadap Kebijakan Dividen Tunai pada Perusahaan Go Public yang Terdaftar pada Indeks Kompas 100 Periode 2011 - 2015. Penelitian ini bertujuan untuk mengetahui pengaruh Earning per Share, Arus Kas Kegiatan Operasi, Likuiditas dan Struktur Modal terhadap Kebijakan Dividen Tunai pada Perusahaan Go Public yang Terdaftar pada Indeks Kompas 100 periode 20112015. Populasi penelitian adalah semua perusahaan yang terdaftar pada Indeks Kompas 100 selama periode 2011-2015 dan diperoleh sampel sebanyak 7 perusahaan dengan menggunakan teknik purposive sampling. Pengumpulan data dilakukan dengan metode dokumentasi dan dianalisis dengan SPSS versi 20 yang meliputi analisis statistik deskriptif, uji asumsi klasik dan uji hipotesis menggunakan regresi linear sederahana dan berganda. Hasil penelitian menunjukkan bahwa Earning per Share dan Arus Kegiatan Operasi berpengaruh positif dan signifikan, Likuiditas berpengaruh positif namun tidak signifikan, Struktur Modal berpengaruh negatif tetapi tidak signifikan dan secara simultan semua variabel independen berpengaruh secara signifikan terhadap Kebijakan Dividen Tunai dengan nilai Adjusted $R^{2}$ sebesar 0,746.
\end{abstract}

Kata kunci: Kebijakan Dividen Tunai, Earning per Share, Arus Kas Kegiatan Operasi, Likuiditas, Struktur Modal, Indeks Kompas 100

Abstract: The Effect of Earning Per Share, Operating Cash Flow, Liquidity and Capital Structure on Cash Dividend Policy in Public Companies Listed on Kompas 100 Index Over the Period 20112015. This study aims to determine the effect of Earning per Share, Operating Cash Flow, Liquidity and Capital Structure on Cash Dividend Policy in Public Companies listed on Kompas 100 Index during 2011-2015 either partially and simultaneously. The population in this study are the companies listed on Kompas 100 Index over the period 2011-2015. Sampling technique used purposive sampling method and got 7 companies as samples. Data was collected by documentation method and analyzed by SPSS version 20 which includes descriptive statistical analysis, classic assumptions test and hypothesis testing using linear regression. The results showed that the variables of Earning per Share and Operating Cash Flow have positive and significant effect, Liquidity has positive but not significant effect, Capital Structure has negative but not significant effect and simultaneously, the four variables significantly influence Cash Dividend Policy with Adjusted $R^{2}$ value of 0.746.

Keywords: Cash Dividend Policy, Earning per Share, Operating Cash Flow, Liquidity, Capital Structure Kompas 100 Index 


\section{JURNAL NOMINAL / VOLUME VI NOMOR 2 / TAHUN 2017}

\section{PENDAHULUAN}

Kebijakan dividen merupakan salah satu kebijakan pendanaan perusahaan yang cukup krusial. Pasalnya, kebijakan ini terkait sejumlah pihak yang memiliki kepentingan saling berlawanan. Pihak tersebut di antaranya: investor, manajemen, kreditor dan pihak lain yang berkepentingan terkait informasi dividen seperti pelaku pasar modal. Telah semestinya jika kebijakan dividen memiliki dampak penting bagi banyak pihak yang terlibat (Suharli, 2007). Penetapan kebijakan dividen menjadi hal krusial apabila kepentingan masing-masing pihak yang bertentangan tersebut ingin diakomodasi seluruhnya. Penelitian terdahulu terkait kebijakan dividen telah banyak dilakukan, namun demikian topik ini masih saja menarik untuk diteliti (Whardana, 2014).

Studi yang dilakukan oleh Eugene Fama dan Kenneth French (2001) menunjukkan adanya penurunan pembayaran dividen di bursa saham Amerika Serikat. Alasan perusahaan tidak membagikan dividen yaitu pendapatan yang negatif serta kebutuhan investasi yang tinggi. Fenomena penurunan pembayaran dividen juga terjadi di Indonesia tahun belakangan. Terdapat indikasi bahwa perusahaan lebih memilih untuk tidak membagikan dividen dan menahan keuntungan sebagai laba ditahan.
Fenomena-fenomena kebijakan dividen yang terjadi seringkali dikaitkan dengan teori dividen, seperti smoothing theory (Lintner, 1956), clientele effect theory (Black dan Scholes, 1974), signalling theory (Bhattacharya, 1979) dan agency theory (Jensen \& Meckling 1976). Terkait teori sinyal, investor akan menangkap informasi atas pembagian dividen sebagai sinyal positif atas prospek perusahaan., Studi terkait persepsi manajemen perusahaan tentang pengaruh kebijakan dividen terhadap nilai perusahaan ini telah dilakukan oleh Baker dan Powell (1999). Hasil penelitian menunjukkan responden meyakini terdapat keterkaitan antara kebijakan dividen dengan nilai perusahaan.

Namun di sisi lain, beberapa perusahaan melakukan strategi sebaliknya yaitu menahan dividen hingga periode tertentu. Microsoft, perusahaan besar dunia yang tidak membagikan dividen dari tahun 1975 hingga 2003. Bahkan di Indonesia, terdapat beberapa perusahaan yang tercatat belum pernah membagikan dividen sejak awal mendaftarkan diri di bursa. satu emiten yang tak pernah membagikan dividen adalah PT Hero Supermarket Tbk dengan argumen perusahaan tengah membutuhkan dana ekspansi sehingga belum akan membagi dividen untuk hasil laba bersih di tahun 2012 meskipun pada kenyataannya laba bersih perusahaan selalu bertumbuh. 


\section{JURNAL NOMINAL / VOLUME VI NOMOR 2 / TAHUN 2017}

Fenomena emiten yang memilih tidak membagi hasil laba bersih dalam bentuk dividen ini menuai reaksi dari BEI. Tindakan yang dilakukan BEI yaitu mencari keterangan dari para emiten yang tidak membagikan dividen dalam tiga tahun terakhir. Tindakan yang dilakukan BEI ini merupakan wujud kepedulian terhadap investor, pasalnya investor memiliki hak atas pembagian laba perusahaan yang salah satunya dalam wujud dividen. Pengamat Pasar Modal menjelaskan bahwa Perlu adanya peraturan dan sanksi tegas mengenai batasan toleransi pembagian dividen. Menanggapi isu tersebut, BEI berencana mengeluarkan kebijakan yang mewajibkan emiten membagi dividen tunai kepada para pemegang saham. Namun, rencana tersebut masih sebatas wacana dan belum terealisasi hingga saat ini.

Kebijakan dividen masih menjadi kajian yang menarik terkait kewajiban pembayaran dividen bagi emiten. Aturan terkait pembayaran dividen di Indonesia mencantumkan bahwa pembayaran dividen bukan merupakan suatu kewajiban. Selain itu, praktiknya kebijakan dividen diputuskan dalam RUPS. Kedua hal tersebut memberikan kebebasan pada perusahaan untuk membayar atau menahan dividen. Hal ini menyiratkan bahwa faktor yang mempengaruhi perusahaan untuk membayarkan dividen masih menjadi misteri (Wardhana : 2014).
Manajemen hendaknya menentukan sasaran rasio pembayaran dividen dengan mendasarkan pada preferensi investor antara dividen tunai atau keuntungan modal (Brigham \& Houston, 2011:211). Kebijakan dividen membawa dua dampak berlawanan, yaitu jika perusahaan meningkatkan rasio pembayaran maka ketersediaan arus kas utuk investasi kembali menjadi lebih sedikit. Hal ini berakibat pada menurunnya kesempatan investasi. Maka, manajemen memerlukan kebijakan dividen optimal yang dapat menghasilkan keseimbangan antara dividen saat ini dan pertumbuhan perusahaan di masa depan.

Brigham \& Houston (2011:218) menyatakan bahwa rasio pembayaran dividen yang optimal merupakan fungsi dari opini manajemen mengenai preferensi investor antara dividen versus keuntungan modal, peluang investasi perusahaan, struktur modal sasaran serta ketersediaan dana modal eksternal. Berdasarkan model ini rasio pembayaran dividen akan bervariasi seiring dengan peluang investasi dan juga variasi laba. Namun apabila perusahaan membayarkan dividen secara fluktuasi, investor dapat menangkapnya sebagai sinyal yang tidak menentu terkait kelangsungan perusahaan. Berdasarkan teori serta fenomena yang telah diuraikan tersebut, penulis tertarik untuk melakukan penelitian terkait determinan yang mempengaruhi kebijakan dividen tunai. 


\section{JURNAL NOMINAL / VOLUME VI NOMOR 2 / TAHUN 2017}

Penelitian terdahulu menemukan beberapa faktor yang mempengaruhi dividen tunai di antaranya: Kepemilikan Managerial, Kepemilikan Institusional, Kebijakan Hutang, Profitabilitas dan Ukuran Perusahaan (Dewi, 2008), Arus Kas Operasi (Manurung dan Siregar, 2009), Profitabilitas dan Struktur Modal (Darminto, 2008), Likuiditas dan Ukuran Perusahaan (Rita, 2015), Leverage dan Pertumbuhan Perusahaan (Permana, 2016). Namun begitu masih terjadi perbedaan hasil penelitian terkait pengaruh determinan Kebijakan Dividen.

Brigham \& Houston (2011:211) menyatakan bahwa pembayaran dividen tunai memperhitungkan ketersediaan dana serta struktur modal sasaran perusahaan, di samping laba yang merupakan komponen dalam perhitungan. Selain itu, pembatasan terkait hutang juga menjadi salah satu faktor yang mempengaruhi dividen tunai. Berdasarkan hasil penelitian terdahulu serta teori-teori yang ada, penulis melakukan penelitian terkait determinan kebijakan dividen tunai meliputi: Earning per Share, Arus Kas Kegiatan Operasi, Likuiditas serta Struktur Modal pada perusahaan go public yang terdaftar pada Indeks Kompas 100 periode 2011 - 2015. Objek penelitian diambil dari Indeks Kompas 100 karena indeks ini berisi perusahaan yang memiliki kategori likuiditas baik, kapitalisasi pasar tinggi, fundamental kuat dan kinerja perusahaan yang baik. Adapun tahun amatan ditentukan selama 5 tahun terakhir yaitu $2011-2015$.

\section{METODE PENELITIAN}

\section{Jenis Penelitian}

Jenis penelitian ini adalah kuantitatif yaitu penelitian yang menggunakan data berupa angka serta prosedur-prosedur statistik untuk menganalisis data (Sujarweni, 2014:39). Penelitian ini termasuk penelitian kausal-komparatif yang berusaha menyelidiki hubungan sebab-akibat melalui pengamatan terhadap konsekuensi yang telah terjadi dan menganalisis data yang ada untuk menemukan faktor-faktor penyebab (Azwar, 2001:9).

\section{Tempat dan Waktu Penelitian}

Penelitian ini dilakukan di Bursa Efek Indonesia dengan mengambil data Laporan Keuangan Tahunan perusahan yang terdaftar pada Indeks Kompas 100 selama periode 2011-2015. Data penelitian diunduh dari website resmi Bursa Efek Indonesia yakni www.idx.co.id. Adapun waktu penelitian dimulai dari bulan November 2016 hingga Maret 2017.

\section{Definisi Operasional}

Variabel Dependen

\section{Kebijakan Dividen Tunai (Y)}

Indikator yang digunakan dalam pengukuran Kebijakan Dividen Tunai adalah Dividend per Share (DPS) yang 


\section{JURNAL NOMINAL / VOLUME VI NOMOR 2 / TAHUN 2017}

dihitung dengan rumus dividen dibagi dengan rata-rata tertimbang saham yang beredar.

\section{Variabel Independen}

Earning per Share $\left(\mathbf{X}_{1}\right)$

Earning per Share mengukur keberhasilan manajemen mencapai keuntungan bagi pemegang saham yang diperhitungkan jumlah keuntungan diurangi pajak, dividen dan hak-hak lain untuk pemegang saham prioritas (Kasmir, 2016:207). EPS dihitung dengan membagi laba yang dapat diatribusikan pada pemegang saham dengan rata-rata tertimbang saham yang beredar.

\section{Arus Kas Kegiatan Operasi $\left(\mathbf{X}_{2}\right)$}

Arus kas kegiatan operasi merupakan arus kas bersih yang berasal dari kegiatan operasional perusahaan seperti penjualan, pembayaran hutang dagang pada pemasok, dan pembayaran biaya usaha. Variabel ini dihitung dengan membagi total Arus Kas Kegiatan Operasi pada Laporan Arus Kas dengan ratar-rata tertimbang saham yang beredar.

\section{Likuiditas ( $\left.\mathbf{X}_{3}\right)$}

Likuiditas

mencerminkan

kemampuan perusahaan untuk mendanai kewajiban jangka pendeknya. Indikator yang digunakan untuk mengukur likuiditas adalah Current Ratio (CR) yang dihitung dengan membagi total Aset Lancar dengan total Liabilitas jangka pendek.

\section{Struktur Modal $\left(\mathbf{X}_{4}\right)$}

Struktur modal menggambarkan proporsi antara hutang dan ekuitas perusahaan yang digunakan untuk pendanaan perusahaan. Informasi untuk menghitung besarnya Struktur Modal yang diproksikan dengan Debt to Equity Ratio (DER) dihitung dengan cara membagi total liabilitas dengan ekuitas.

\section{Populasi dan Sampel}

Populasi penelitian meliputi seluruh perusahaan go public yang terdaftar pada Indeks Kompas 100 selama periode 2011 2015 sejumlah 193 emiten. Pengambilan sampel dilakukan dengan metode purposive sampling didasarkan pada kriteria berikut:

1. Perusahaan terdaftar di Indeks Kompas 100 selama periode 2011 - 2015 dan tidak pernah keluar dari indeks.

2. Bukan termasuk perusahaan perbankan.

3. Perusahaan menerbitkan Laporan Keuangan Tahunan selama periode 2011-2015.

4. Laporan Keuangan dicantumkan dalam mata uang Rupiah.

5. Perusahaan melaksanakan kebijakan dividen tunai selama $2011-2015$.

Berdasarkan kriteria-kriteria tersebut di atas, maka terdapat 7 perusahaan yang layak dijadikan sampel dalam penelitian ini.

\section{Metode Pengumpulan Data}

Metode pengumpulan data pada penelitian ini adalah metode dokumentasi 


\section{JURNAL NOMINAL / VOLUME VI NOMOR 2 / TAHUN 2017}

yaitu mengumpulkan data sekunder berupa laporan keuangan melalui website resmi Bursa Efek Indonesia yaitu www.idx.co.id.

\section{Teknik Analisis Data}

Teknik analisis data pada penelitian ini dilakukan dengan bantuan software SPSS versi 20. Adapun jenis analisis yang dipergunakan meliputi analisis statistik deskriptif, uji asumsi klasik dan uji hipotesis menggunakan regresi linear.

\section{Statistik Deskriptif}

Definisis teknik analisis statistik deskriptif adalah teknik analisis yang digunakan untuk menggambarkan ringkasan data penelitian yang meliputi mean, standar deviasi, varian, modus, dan lain-lain (Priyatno, 2013:66). Tujuan dari analisis deskriptif adalah memberikan deskripsi mengenai subjek penelitian berdasarkan data dari variabel yang telah diperoleh.

\section{Uji Asumsi Klasik}

\section{Uji Normalitas}

Uji normalitas bertujuan untuk mengetahui kenormalan distribusi data pada variabel, baik variabel dependen maupun independen. Ghozali (2011:160) menyatakan bahwa uji ini menjamin bahwa variabel pengganggu atau residual berdistribusi normal. Uji normalitas dalam penelitian ini dilakukan dengan uji One Sample Kolmogorov-Smirnov. Data penelitian dapat dikatakan normal apabila signifikansinya lebih besar dari 0,05 .

\section{Uji Multikolinearitas}

Menurut Priyatno (2014:48) model regresi yang baik adalah yang tidak terdapat masalah multikolinearitas. Analisis dalam penelitian ini menggunakan metode pertama yaitu dengan mempertimbangkan nilai tolerance dan VIF. Kriteria yang ditetapkan untuk uji ini yaitu nilai Tolerance harus lebih besar dari 0,1 dan nilai VIF kurang dari 10 (Ghozali, 2011:106).

\section{Uji Autokorelasi}

Autokorelasi adalah korelasi antara sesama urutan pengamatan dari waktu ke waktu (Umar, 2001:143). Pengujian ini bertujuan untuk menghindari masalah autokorelasi yang mengakibatkan penaksiran dengan kuadrat terkecil akan sangat sensitif terhadap fluktuasi sampel dan penaksiran menjadi tidak efisien. Adapun uji yang digunakan adalah DurbinWatson dengan kriteria nilai DW berkisar antara dU hingga 4-dU.

\section{Uji Heteroskedastisitas}

Ghozali (2011:139) menjelaskan bahwa uji heteroskedastisitas bertujuan untuk menguji masalah ketidaksamaan variance dari residual satu pengamatan ke pengamatan lain. Pengujian dilakukan uji dengan Glejser yaitu dengan mengkorelasikan nilai absolut residual dengan masing-masing variabel independen. Apabila nilai sig.>0,05 dapat dikatakan lolos dari masalah heteroskedastisitas. 


\section{JURNAL NOMINAL / VOLUME VI NOMOR 2 / TAHUN 2017}

\section{Uji Hipotesis}

\section{Analisis Regresi Linear Sederhana}

Analisis regresi linear sederhana digunakan untuk menguji pengaruh Earning per Share, Arus Kas Kegiatan Operasi, Likuiditas dan Struktur Modal terhadap Kebijakan Dividen secara parsial. Pengujian ini dilakukan dengan uji-t untuk memberikan gambaran besarnya signifikansi pengaruh variabel independen terhadap variabel dependen secara parsial. Guna mengetahui besarnya signifikansi tersebut, maka dibandingkan nilai thitung dengan $t_{\text {tabel. }}$ Apabila nilai thitung lebih besar dibandingkan nilai $t_{\text {tabel }}$ pada taraf signifikansi 5\%, maka dapat disimpulkan bahwa variabel independen berpengaruh signifikan terhadap variabel dependen dan sebaliknya.

\section{Analisis Regresi Berganda}

Analisis digunakan untuk menguji pengaruh Earning per Share, Arus Kas Kegiatan Operasi, Likuiditas dan Struktur Modal secara bersama-sama terhadap Kebijakan Dividen. Uji signifikansi regresi berganda menggunakan uji-F untuk mengetahui pengaruh variabel independen secara bersama-sama terhadap variabel dependen. Cara mengukur signifikansi tersebut adalah dengan membandingkan nilai $F_{\text {hitung }}$ dengan $F_{\text {tabel. }}$ Apabila nilai $F_{\text {hitung }}$ lebih besar daripada $F_{\text {tabel }}$ pada tingkat signifikansi 5\% maka dapat disimpulkan bahwa variabel independen berpengaruh signifikan terhadap variabel dependen dan sebaliknya.

\section{Koefisien Determinasi $\left(R^{2}\right)$}

Koefisien determinasi digunakan untuk mengukur kemampuan model regresi dalam menerangkan variasi variabel dependen.

\section{HASIL PENELITIAN DAN PEMBA-} HASAN

\section{Statistik Deskriptif}

Berdasarkan data sampel yang telah diperoleh maka dilakukan analisis statistik deskriptif guna mengetahui nilai minimum, maksimum, dan rata-rata tiap variabel.

Tabel 1. Hasil Analisis Statistik Deskriptif

\begin{tabular}{|l|r|r|r|r|r|}
\hline & N & Minimum & Maximum & \multicolumn{1}{|c|}{ Mean } & $\begin{array}{c}\text { Std. } \\
\text { Deviation }\end{array}$ \\
\hline & \multicolumn{1}{|c|}{35} & 17,00 & $1.350,00$ & 356,3796 & 305,18593 \\
\hline DPS & 35 & 31,62 & $1.656,58$ & 734,5256 & 520,94590 \\
\hline EPS & 35 & 19,78 & $3.924,70$ & $1.004,0173$ & 973,02426 \\
\hline AKKO & 35 & 1,24 & 6,99 & 2,9651 & 1,55516 \\
\hline CR & 35 & 1,03 & 0,4633 & 0,28359 \\
\hline DER & 35 & 0,15 & & & \\
\hline
\end{tabular}

Berdasarkan analisis tersebut dapat diketahui bahwa nilai standar deviasi semua variabel lebih kecil dari nilai ratarata variabel. Hal tersebut berarti sebaran data baik dan bersifat homogen.

\section{Hasil Uji Asumsi Klasik}

Sebelum uji hipotesis dilakukan uji asumsi klasik terlebih dahulu untuk memastikan data memenuhi persyaratan untuk diuji regresi. Uji asumsi klasik dalam penelitian ini meliputi: uji normalitas, multikolinearitas, autokorelasi dan heteroskedastisitas. 


\section{JURNAL NOMINAL / VOLUME VI NOMOR 2 / TAHUN 2017}

\section{Uji Normalitas}

Tabel 2. Uji Normalitas

\begin{tabular}{|c|c|c|}
\hline One-Sal & lmogorov-s & $\begin{array}{l}\text { rnov Test } \\
\text { Unstandardized } \\
\quad \text { Residual }\end{array}$ \\
\hline $\mathrm{N}$ & & 35 \\
\hline Normal & Mean & OE-7 \\
\hline Parametersab & $\begin{array}{l}\text { Std. } \\
\text { Deviation }\end{array}$ & 144,46125641 \\
\hline Most Extreme & Absolute & 0,206 \\
\hline Differences & $\begin{array}{l}\text { Positive } \\
\text { Negative }\end{array}$ & $\begin{array}{r}0,206 \\
-0,116\end{array}$ \\
\hline \multicolumn{2}{|c|}{ Kolmogorov-Smirnov $Z$} & 1,211 \\
\hline \multicolumn{2}{|c|}{$\begin{array}{l}\text { Asymp. Sig. (2-tailed) } \\
\text { a. Test distribution is Normal. } \\
\text { b. Calculated from data. }\end{array}$} & 0,102 \\
\hline
\end{tabular}

Berdasarkan data di atas nilai Asymp.

Sig (2-tailed) sebesar 1,211, lebih dari tingkat signifikansi 0,05 maka dapat dikatakan data berdistribusi normal.

\section{Uji Multikolinearitas}

Tabel 3. Uji Multikolinearitas

\begin{tabular}{|l|r|r|r|r|r|r|r|}
\hline \multirow{2}{*}{ Model } & \multicolumn{2}{|c|}{$\begin{array}{c}\text { Unstandardized } \\
\text { Coefficients }\end{array}$} & $\begin{array}{c}\text { Standardized } \\
\text { Coefficients }\end{array}$ & \multirow{2}{*}{$t$} & \multirow{2}{*}{ Sig. } & \multicolumn{2}{|c|}{$\begin{array}{c}\text { Collinearity } \\
\text { Statistics }\end{array}$} \\
\cline { 2 - 3 } & \multicolumn{1}{c|}{$B$} & \multicolumn{1}{c|}{$\begin{array}{c}\text { Std. } \\
\text { Error }\end{array}$} & \multicolumn{1}{c|}{ Beta } & & & Tolerance & VIF \\
\hline (Constant) & $-38,452$ & 130,007 & & $-0,296$ & 0,769 & & \\
EPS & 0,529 & 0,104 & 0,903 & 5,100 & 0,000 & 0,238 & 4,194 \\
AKKO & $-0,015$ & 0,052 & $-0,047$ & $-0,285$ & 0,777 & 0,270 & 3,698 \\
CR & 13,449 & 27,997 & 0,069 & 0,480 & 0,634 & 0,367 & 2,725 \\
DER & $-39,895$ & 142,492 & $-0,037$ & $-0,280$ & 0,781 & 0,426 & 2,347 \\
\hline
\end{tabular}

Berdasarkan hasil uji dapat diketahui bahwa nilai Torelance dari semua variabel independen lebih besar dari 0,1 dan VIF kurang dari 10, maka persamaan regresi dapat dikatakan terbebas dari masalah korelasi antar variabel independennya.

\section{Uji Autokorelasi}

Tabel 4. Uji Autokorelasi

\begin{tabular}{|l|c|r|r|r|r|}
\hline Model & $R$ & $\begin{array}{c}R \\
\text { Square }\end{array}$ & $\begin{array}{c}\text { Adjusted } R \\
\text { Square }\end{array}$ & $\begin{array}{l}\text { Std. Error of } \\
\text { the Estimate }\end{array}$ & $\begin{array}{l}\text { Durbin- } \\
\text { Watson }\end{array}$ \\
\hline 1 & 0,881 & 0,776 & 0,746 & 153,79075 & 2,038 \\
\hline
\end{tabular}

Berdasarkan hasil uji statistik diperoleh nilai DW sebesar 2,038 yang berada pada range dU sebesar 1,7259 serta 4-dU sebesar 2,2741 sehingga dapat disimpulkan model regresi terbebas dari masalah autokorelasi.

\section{Uji Heteroskedastisitas}

Tabel 5. Uji Heteroskedastisitas

\begin{tabular}{|l|r|r|r|r|r|}
\hline \multirow{2}{*}{ Model } & \multicolumn{2}{|c|}{$\begin{array}{c}\text { Unstandardized } \\
\text { Coefficients }\end{array}$} & $\begin{array}{c}\text { Standardized } \\
\text { Coefficients }\end{array}$ & \multirow{2}{*}{$t$} & \multirow{2}{*}{ Sig. } \\
\cline { 2 - 5 } & \multicolumn{1}{|c|}{$B$} & Std. Error & \multicolumn{1}{c|}{ Beta } & & \\
\hline (Constant) & $-89,808$ & 74,805 & & $-1,201$ & 0,239 \\
EPS & 0,100 & 0,060 & 0,455 & 1,681 & 0,103 \\
AKKO & 0,000 & 0,030 & 0,047 & 0,184 & 0,855 \\
CR & 30,758 & 16,110 & 0,416 & 1,909 & 0,066 \\
DER & 12,440 & 81,990 & 0,031 & 0,152 & 0,880 \\
\hline
\end{tabular}

Berdasarkan hasil uji diperoleh nilai signifikansi semua variabel independen di atas 0,05 maka semua variabel independen tidak berpengaruh secara signifikan terhadap nilai absolute residual atau lolos masalah heteroskedastisitas.

\section{Hasil Uji Hipotesis}

Pengaruh Earning per Share terhadap Kebijakan Dividen Tunai

Tabel 6. Hasil Uji Regresi Linear Sederhana untuk Pengaruh Earning per Share terhadap Kebijakan Dividen Tunai

\begin{tabular}{|l|r|r|r|r|r|}
\hline \multirow{2}{*}{ Model } & \multicolumn{2}{|c|}{$\begin{array}{c}\text { Unstandardized } \\
\text { Coefficients }\end{array}$} & $\begin{array}{c}\text { Standardized } \\
\text { Coefficients }\end{array}$ & \multirow{2}{*}{$t$} & \multirow{2}{*}{ Sig. } \\
\cline { 2 - 4 } & \multicolumn{1}{|c|}{$B$} & Std. Error & \multicolumn{1}{c|}{ Beta } & & \\
\hline (Constant) & $-19,810$ & 44,372 & & $-0,446$ & 0,658 \\
EPS & 0,512 & 0,050 & 0,874 & 10,344 & 0,000 \\
\hline
\end{tabular}

Berdasarkan hasil uji tersebut diperoleh nilai koefisien regresi sebesar 0,512 dengan signifikansi sebesar 0,000. Nilai koefisien tersebut menunjukkan bahwa EPS berpengaruh positif terhadap DPS. Nilai t-tabel dengan $\alpha=0,05, n=35, k=4$ adalah sebesar 2,04227, sementara nilai thitung adalah 10,344 dengan nilai signifikansi sebesar 0,000. Berdasarkan 


\section{JURNAL NOMINAL / VOLUME VI NOMOR 2 / TAHUN 2017}

data tersebut maka $t_{\text {hitung }}>t_{\text {tabel }}$ dan nilai Sig. $<0,05$ menunjukkan bahwa Earning per Share berpengaruh secara signifikan terhadap Kebijakan Dividen Tunai.

\section{Pengaruh Arus Kas Kegiatan Operasi terhadap Kebijakan Dividen Tunai}

Tabel 7. Hasil Uji Regresi Linear Sederhana untuk Pengaruh Arus Kas Kegiatan Operasi terhadap Kebijakan Dividen Tunai

\begin{tabular}{|l|r|r|r|r|r|}
\hline \multirow{2}{*}{ Model } & \multicolumn{2}{|c|}{$\begin{array}{c}\text { Unstandardized } \\
\text { Coefficients }\end{array}$} & $\begin{array}{c}\text { Standardized } \\
\text { Coefficients }\end{array}$ & \multirow{2}{*}{$t$} & \multirow{2}{*}{ Sig. } \\
\cline { 2 - 4 } & \multicolumn{1}{c|}{$B$} & Std. Error & \multicolumn{1}{c|}{ Beta } & & \\
\hline (Constant) & 140,527 & 55,197 & & 2,546 & 0,016 \\
AKKO & 0,215 & 0,040 & 0,685 & 5,408 & 0,000 \\
\hline
\end{tabular}

Berdasarkan hasil uji tersebut diperoleh nilai koefisien regresi sebesar 0,215 dengan signifikansi sebesar 0,000 . Nilai koefisien tersebut menunjukkan bahwa AKKO berpengaruh positif terhadap DPS. Nilai $t_{\text {tabel }}$ dengan $\alpha=0,05$, $\mathrm{n}=35, \quad \mathrm{k}=4$ adalah sebesar 2,04227, sementara nilai thitung adalah 5,408 dengan nilai signifikansi sebesar 0,000 . Berdasarkan data tersebut maka $t_{\text {hitung }}>t_{\text {tabel }}$ dan nilai Sig.<0,05 menunjukkan bahwa Arus Kas Kegiatan Operasi berpengaruh secara signifikan terhadap Kebijakan Dividen Tunai.

\section{Pengaruh Likuiditas terhadap}

\section{Kebijakan Dividen Tunai}

Tabel 8. Hasil Uji Regresi Linear Sederhana untuk Pengaruh Likuiditas terhadap Kebijakan Dividen Tunai

\begin{tabular}{|c|c|c|c|c|c|}
\hline \multirow[t]{2}{*}{ Model } & \multicolumn{2}{|c|}{$\begin{array}{l}\text { Unstandardized } \\
\text { Coefficients }\end{array}$} & \multirow{2}{*}{$\begin{array}{c}\begin{array}{c}\text { Standardized } \\
\text { Coefficients }\end{array} \\
\text { Beta }\end{array}$} & \multirow[t]{2}{*}{$t$} & \multirow[t]{2}{*}{ Sig. } \\
\hline & $B$ & Std. Error & & & \\
\hline (Constant) & 197,196 & 109,674 & & 1,798 & 0,081 \\
\hline $\mathrm{CR}$ & 53,686 & 32,858 & 0,274 & 1,634 & 0,112 \\
\hline
\end{tabular}

Berdasarkan hasil uji tersebut diperoleh nilai koefisien regresi sebesar 53,686 dengan signifikansi sebesar 0,112. Nilai koefisien tersebut menunjukkan bahwa CR berpengaruh positif terhadap DPS. Nilai t-tabel dengan $\alpha=0,05, n=35, k=4$ adalah sebesar 2,04227, sementara nilai $t_{\text {hitung adalah }}$ 1,634 dengan nilai signifikansi sebesar 0,112. Berdasarkan data tersebut maka $t_{\text {hitung }}<\mathrm{t}_{\text {tabel }}$ dan nilai Sig.>0,05 menunjukkan bahwa Likuiditas tidak berpengaruh secara signifikan terhadap Kebijakan Dividen Tunai.

\section{Pengaruh Struktur Modal terhadap Kebijakan Dividen Tunai \\ Tabel 9. Hasil Uji Regresi Linear} Sederhana untuk Pengaruh Struktur Modal terhadap Kebijakan Dividen Tunai

\begin{tabular}{|c|r|r|r|r|r|}
\hline \multirow{2}{*}{ Model } & \multicolumn{2}{|c|}{$\begin{array}{c}\text { Unstandardized } \\
\text { Coefficients }\end{array}$} & $\begin{array}{c}\text { Standardized } \\
\text { Coefficients }\end{array}$ & \multirow{2}{*}{$t$} & \multirow{2}{*}{ Sig. } \\
\cline { 2 - 4 } & \multicolumn{1}{|c|}{$B$} & Std. Error & \multicolumn{1}{|c|}{ Beta } & & \\
\hline \multirow{2}{*}{ (Constant) $^{\text {(Con }}$} & 365,278 & 101,343 & & 3,604 & 0,001 \\
DER & $-19,208$ & 187,302 & $-0,018$ & $-0,103$ & 0,919 \\
\hline
\end{tabular}

Berdasarkan hasil uji tersebut diperoleh nilai koefisien regresi sebesar 19,208 dengan signifikansi sebesar 0,919. Nilai koefisien tersebut menunjukkan bahwa DER berpengaruh negatif terhadap DPS. Nilai t-tabel dengan $\alpha=0,05, n=35, k=4$ adalah sebesar 2,04227, sementara nilai $t_{\text {hitung }}$ adalah $-0,103$ dengan nilai signifikansi sebesar 0,919. Berdasarkan data tersebut maka $t_{\text {hitung }}<t_{\text {tabel }}$ dan nilai 


\section{JURNAL NOMINAL / VOLUME VI NOMOR 2 / TAHUN 2017}

Sig.>0,05 menunjukkan bahwa Struktur Modal tidak berpengaruh secara signifikan terhadap Kebijakan Dividen Tunai.

Pengaruh Earning per Share, Arus Kas Kegiatan Operasi, Likuiditas dan Struktur Modal Terhadap Kebijakan Dividen

Tabel 10. Hasil Uji regresi Linear Berganda untuk Pengaruh Earning per Share, Arus Kas Kegiatan Operasi, Likuiditas dan Struktur Modal Terhadap Kebijakan Dividen Tunai

\begin{tabular}{|l|r|c|r|c|l|}
\hline \multicolumn{1}{|c|}{ Model } & \multicolumn{1}{|c|}{ Sum of Squares } & Df & Mean Square & \multicolumn{1}{c|}{ S } & \multicolumn{1}{c|}{ Sig. } \\
\hline Regression & $2.457 .159,422$ & 4 & $614.289,855$ & 25,972 & $0,000^{\circ}$ \\
Residual & $709.547,857$ & 30 & $23.651,595$ & & \\
Total & $3.166 .707,278$ & 34 & & & \\
\hline
\end{tabular}

Berdasarkan hasil uji diperoleh nilai $F_{\text {hitung }}$ sebesar 25,972 dengan signifikasi 0,000. Selanjutnya, $F_{\text {tabel }}$ dengan $n=35$ dan $\mathrm{k}=4$ sebesar 2,68, dengan demikian nilai $F_{\text {hitung }}>F_{\text {tabel }}$ serta nilai Sig. $<0,05$ dapat disimpulkan bahwa Earning per Share, Arus Kas Kegiatan Operasi, Likuiditas dan Struktur Modal secara simultan berpengaruh secara signifikan terhadap Kebijakan Dividen Tunai.

Tabel 11. Hasil Uji regresi Linear Berganda untuk Persamaan Regresi

\begin{tabular}{|l|r|r|r|r|r|}
\hline \multirow{2}{*}{ Model } & \multicolumn{2}{|c|}{$\begin{array}{c}\text { Unstandardized } \\
\text { Coefficients }\end{array}$} & $\begin{array}{c}\text { Standardized } \\
\text { Coefficients }\end{array}$ & \multirow{2}{*}{$t$} & \multirow{2}{*}{ Sig. } \\
\cline { 2 - 5 } & \multicolumn{1}{c|}{$B$} & \multicolumn{1}{|c|}{ Std. Error } & \multicolumn{1}{c|}{ Beta } & & \\
\hline (Constant $)$ & $-38,452$ & 130,007 & & $-0,296$ & 0,769 \\
EPS & 0,529 & 0,104 & 0,903 & 5,100 & 0,000 \\
AKKO & $-0,015$ & 0,052 & $-0,047$ & $-0,285$ & 0,777 \\
CR & 13,449 & 27,997 & 0,069 & 0,480 & 0,634 \\
DER & $-39,895$ & 142,492 & $-0,037$ & $-0,280$ & 0,781 \\
\hline
\end{tabular}

Berdasarkan hasil uji tersebut dapat dibuat persamaan untuk memprediksi nilai DPS yaitu:

DPS $=-38,452+(0,529 *$ EPS $)$

$(0,015 * \mathrm{AKKO})+(13,449 * \mathrm{CR})$

$(39,895 * \mathrm{DER})+\mathrm{e}$

Tabel 12. Hasil Uji regresi Linear Berganda untuk Koefisien Determinasi

\begin{tabular}{|l|c|r|r|r|}
\hline Model & $R$ & $R$ Square & $\begin{array}{c}\text { Adjusted } R \\
\text { Square }\end{array}$ & $\begin{array}{c}\text { Std. Error of } \\
\text { the Estimate }\end{array}$ \\
\hline 1 & $0,881^{\mathrm{a}}$ & 0,776 & 0,746 & 153,79075 \\
\hline
\end{tabular}

Berdasarkan hasil uji diperoleh nilai Adjusted $R^{2}$ sebesar 0,746 yang berarti bahwa sebesar 74,6\% variasi Kebijakan Dividen Tunai dapat dijelaskan oleh variasi Earning per Share, Arus Kas Kegiatan Operasi, Likuiditas dan Struktur Modal dan sisanya sebesar $25,4 \%$ dijelaskan oleh faktor lain di luar penelitian ini

\section{SIMPULAN DAN SARAN}

\section{Simpulan}

Berdasarkan hasil analisis data dapat ditarik kesimpulan bahwa:

1. Earning per Share berpengaruh positif dan signifikan terhadap Kebijakan Dividen Tunai, dibuktikan dengan nilai koefisien $\quad 0,512$ serta signifikansi sebesar 0,000 .

2. Arus Kas Kegiatan Operasi berpengaruh positif dan signifikan terhadap Kebijakan Dividen Tunai, dibuktikan dengan nilai koefisien sebesar 0,215 serta signifikansi sebesar 0,000. 


\section{JURNAL NOMINAL / VOLUME VI NOMOR 2 / TAHUN 2017}

3. Likuiditas berpengaruh positif tetapi tidak signifikan terhadap Kebijakan Dividen Tunai, dibuktikan dengan nilai koefisien 53,686 serta signifikansi sebesar 0,112 .

4. Struktur Modal berpengaruh negatif tetapi tidak signifikan terhadap Kebijakan Dividen Tunai, dibuktikan dengan nilai koefisien $-19,208$ serta signifikansi sebesar 0,919 .

5. Earning per Share, Arus Kas Kegiatan Operasi, Likuiditas dan Struktur Modal secara simultan berpengaruh signifikan terhadap Kebijakan Dividen Tunai, dibuktikan dengan nilai $F_{\text {hitung }}$ sebesar 25,972 dan signifikansi 0,000.

6. Hasil penelitian menunjukkan $74,6 \%$ variasi Kebijakan Dividen Tunai dapat dijelaskan oleh variasi Earning per Share, Arus Kas Kegiatan Operasi, Likuiditas dan Struktur Modal, sisanya dijelaskan oleh faktor lain di luar penelitian ini.

\section{Keterbatasan}

Penelitian ini masih memiliki beberapa keterbatasan, antara lain:

1. Penelitian menggunakan sampel dari perusahaan dengan karakteristik industri yang berbeda sehingga dimungkinkan terdapat industrial effect pada hasil penelitian.

2. Jumlah sampel sedikit karena penetapan kriteria sampling yang mensyaratkan perusahaan berturut- turut membagikan dividen selama periode amatan.

3. Penelitian menggunakan variabel Arus Kas Kegiatan Operasi dan tidak mempertimbangkan arus kas dari kegiatan investasi dan pendanaan.

4. Variabel independen yang digunakan hanya meliputi variabel yang terkait dengan laporan keuangan perusahaan dan tidak memasukkan variabel yang berada di luar perusahaan.

\section{Saran}

Berdasarkan keterbatasan yang telah diuraikan tersebut, dapat disampaikan beberapa saran untuk penelitian selanjutnya sebagai berikut:

1. Mengambil objek pada sektor-sektor industri tertentu untuk menghindari adanya industrial effect.

2. Memperbaiki kriteria sampling terkait pembayaran dividen berturut-turut selama periode amatan.

3. Mengembangkan variabel terkait ketersediaan dana tidak hanya pada Arus Kas Kegiatan Operasi tetapi juga mencakup Arus Kas Kegiatan Investasi dan Pendanaan.

4. Mengembangkan sampel penelitian tidak terbatas pada perusahaan yang terdaftar pada Indeks Kompas 100.

5. Mengembangkan periode amatan menjadi lebih panjang.

6. Memasukkan variabel yang berada di luar laporan keuangan yang belum diamati dalam penelitian ini. 


\section{JURNAL NOMINAL / VOLUME VI NOMOR 2 / TAHUN 2017}

\section{DAFTAR PUSTAKA}

Ananditha, I. G. (2012). Pengaruh Cash Ratio, Debt to Equity Ratio, dan Return On Asset terhadap Kebijakan Dividen pada Perusahaan Manufaktur di Bursa Efek Indonesia. Tesis. Universitas Udayana, Denpasar.

Atmaja, L. S. (1994). Manajemen Keuangan (Buku 1). Yogyakarta: Andi Offset. . (2016). Emiten Wajib Bagi Dividen. Diakses tanggal 20 Januari 2017 dari http://kolom.kontan.co.id/news/611/ Emiten-wajib-bagi-dividen.

Azwar, S. (2001). Metode Penelitian (Edisi I Cetakan III). Yogyakarta: Pustaka Pelajar.

Baker, H. K., \& Powell, G. E. (1999). How Corporate Managers View Dividend Policy. Quarterly Journal of Business and Economics. Vol. 38, No. 2 (Spring 1999), pp. 17 -35.

Baridwan, Z. (2010). Intermediate Accounting (Edisi Kedelapan). Yogyakarta: BPFE Yogyakarta.

Brigham, E. F., \& Houston, J. F. (2011). Essentials of Financial Management (Edisi Kesebelas). Jakarta: Salemba Empat.

Darminto. (2008). Pengaruh Profitabilitas, Likuiditas, Struktur Modal dan Struktur Kepemilikan Saham terhadap Kebijakan Dividen. Jurnal Ilmu-Ilmu Sosial. Vol. 20-no.2.

Dewi, S. C. (2008). Pengaruh Kepemilikan Managerial, Kepemilikan Institusional, Kebijakan Hutang, Profitabilitas dan Ukuran Perusahaan terhadap Kebijakan Dividen. Jurnal Bisnis dan
Akuntansi. Vol. 10, No.1, hlm. 4758.

Dyckman, T. R., Roland, E. D., \& Charles, J. D. (1999). Akuntansi Intermediate (Jilid 1 Edisi Ketiga). (Alih Bahasa Munir Ali). Jakarta: Penerbit Erlangga.

Ghozali, I. (2011). Aplikasi Analisis Multivariate dengan Program SPSS. Semarang: Badan Penerbit Universitas Diponegoro.

Ikatan Akuntansi Indonesia. (2002). Standar Akuntansi Keuangan. Jakarta: Salemba Empat.

Irawan, D., \& Nurdhiana. (2012). Pengaruh Laba Bersih dan Arus Kas Operasi Terhadap Kebijakan Dividen pada Perusahaan yang Terdaftar di Bursa Efek Indonesia Periode 20092010. E-Jurnal Widyamanggala. Vol. 1, No.1.

Komang, A. N. S. \& Sudjarni, L. K. (2015). Pengaruh Likuiditas, Leverage, Pertumbuhan Perusahaan, dan Profitabilitas terhadap Kebijakan Dividen pada Perusahaan Manufaktur di BEI. E-jurnal Manajemen Universitas Udayana. Vol. 4, No.10, 2015:3346-3374, ISSN: 2302-8912.

Hartono, J. (2014). Teori Portofolio dan Analisis Investasi (Edisi Kesembilan). Yogyakarta: BPFE.

Kasmir. (2016). Analisis Laporan Keuangan (Edisi 1, Cetakan ke-9). Jakarta: PT Raja Grafindo Persada.

Keown, A. J., David F. S., John D. M., et al. (2000). Dasar-Dasar Manajemen Keuangan (Buku 2). (Diterjemahkan oleh Chaerul D. Djakman dan Dwi Sulisyorini). Jakarta: Penerbit Salemba Empat. 
Kieso, D. E., \& Weygandt, J. J. (1995). Akuntansi Intermediate (Edisi Ketujuh Jilid Dua). (Alih bahasa: Herman Wibowo). Jakarta Barat: Binarupa Aksara.

Lihhiati. (2013). Pengembangan Usaha, Alasan Tidak Bagi Dividen - Perlu Aturan Tegas. Diakses tanggal 21 Januari 2017 dari http://www.neraca.co.id/article/2456 2/pengembangan-usaha-alasan-tidakbagi-dividen-perlu-aturan-tegas.

Mamduh. (2013). Manajemen Keuangan (Edisi 1). Yogyakarta: BPFE Yogyakarta.

Manurung, I. A. (2009). Pengaruh Laba Bersih dan Arus Kas Operasi terhadap Kebijakan Dividen pada Perusahaan Manufaktur yang Go Publik. Skripsi. Universitas Sumatera Utara, Medan.

Marlina, L., \& Danica, C. (2009). Analisis Pengaruh Cash Position, Debt to Equity Ratio, dan Return on Assets Terhadap Dividend Payout Ratio. Jurnal Manajemen Bisnis.

Melani, A. (2016). Strategi Sampoerna Dongkrak Investor Ritel di Pasar Modal. Diakses tanggal 18 Januari 2017 dari

http://bisnis.liputan6.com/read/24942 00/strategi-sampoerna-dongkrakinvestor-ritel-di-pasar-modal.

Nurdiana, A. (2013). BEI Bakal Atur Emiten Tak Bagi Dividen. Diakses tanggal 20 Januari 2017 dari http://investasi.kontan.co.id/news/bei -bakal-atur-emiten-tak-bagi-dividen.

Permana, H. A. (2016). Analisis Pengaruh Leverage, Likuiditas, Profitabilitas, Pertumbuhan Perusahaan dan Ukuran Perusahaan Terhadap Kebijakan Dividen pada Perusahaan Manufaktur yang Terdaftar di BEI.
Skripsi. Universitas Negeri

Yogyakarta, Yogyakarta.

Priyatno, D. (2013). Olah Data Statistik dengan Program PSPP. Yogyakarta: MediaKom.

Puspita, F. (2009). Analisis Faktor-Faktor Yang Mempengaruhi Kebijakan Dividend Payout Ratio. Tesis. Universitas Diponegoro Semarang, Semarang.

Rahmawati, W. T. (2013). Aturan Wajib Membagi Dividen Belum Jadi. Diakses tanggal 20 Januari 2017 dari http://investasi.kontan.co.id/news/atu ran-wajib-membagi-dividen-belumjadi.

Rita, S. N. (2015). Pengaruh Arus Kas, Likuiditas, Laba Bersih dan Ukuran Perusahaan terhadap Kebijakan Pembagian Dividen pada Perusahaan Manufaktur Go Publik yang Terdaftar di Bursa Effek Indonesia periode 2010-2013. Artikel Skripsi. Universitas Nusantara PGR Kediri,Kediri.

Riyanto, B. (1994). Dasar-Dasar Pembelanjaan Perusahaan (Edisi Tiga Cetakan Ketujuhbelas). Yogyakarta: Yayasan Badan Penerbit Gadjah Mada.

Rizaldi, M. N. (2013). Analisis FaktorFaktor Yang Mempengaruhi Kebijakan Dividend Payout Ratio. Jurnal Manajemen Bisnis.

Sjahrial, D. (2010). Manajemen Keuangan (Edisi Keempat). Jakarta: Penerbit Mitra Wacana Media.

Smith, J. M., \& Skousen, K. F. (1987). Intermediate Accounting Comprehensive Volume (Ninth Edition). Cincinnati, Ohio: SouthWestern Publishing Co.

Stice, E.K., Stice, J. D., \& Skousen, F. (2005). Akuntansi Keuangan 
Menengah (Jilid 1). Jakarta: Erlangga.

Subramanyam, K.R. (2010). Financial Statement Analysis (Edisi Kesepuluh). Jakarta: Salemba Empat.

Sugiyono, (2009). Metode Penelitian Kuantitatif Kualitatif dan $R \& D$. Bandung: Alfabeta.

Suharli, M. (2006). Studi Empiris Mengenai Pengaruh Profitabilitas, Leverage, dan Harga Saham Terhadap Jumlah Dividen Tunai (Studi pada Perusahaan yang Terdaftar di Bursa Efek Jakarta Periode 2002-203). Jurnal MAKSI. Vol. 6 No. 2 Agustus 2006 : 243 256.

. (2007). Pengaruh Profitability dan Investment Opportunity Set terhadap Kebijakan Dividen Tunai dengan Likuiditas sebagai Variabel Penguat. Jurnal Akuntansi dan Keuangan. Vol. 9 No. 1, MF1 2007: 9-17.

Sujarweni, V. W. (2014). Metodologi Penelitian. Yogyakarta: Pustaka Baru Press.

Sunyoto, D. (2013). Metodologi Penelitian Akuntansi. Bandung: PT Refika Aditama.

Tampubolon, M. P. (2005). Manajemen Keuangan (Finance Management) Konseptual, Problem \& Studi Kasus. Bogor: Ghalia Indonesia.

Taqqiyah., B. (2016). Bagi Dividen Saham, Saham GGRM Terbang. Diakses tanggal 18 Januari 2017 dari http://investasi.kontan.co.id/news/ba gi-dividen-saham-ggrm-terbang.

Umar, H. (2001). Metode Penelitian untuk Skripsi dan Tesis Bisnis. Jakarta: Rajawali Pers.
Wardhana, L. I., et. al. (2014). Dividend Policy in Indonesia: A Life-Cycle Explanation. Asian Finance Association (AsianFA) 2014 Conference Paper.

Warsono. (2003). Manajemen Keuangan Perusahaan (Edisi Ketiga Jilid I). Malang: Banyumedia.

http://www.idx.co.id/idid/beranda/perusahaantercatat/lapora nkeuangandantahunan.aspx (Diakses tanggal 21 Januari 2017)

http://www.sahamok.com/bei/kompas-100/ (Diakses tanggal 18 Desember 2016) 